\title{
Deteksi Dispensing Error Pada Peresepan Sediaan Kapsul Racikan di Apotek Wilayah Kecamatan Samarinda Ulu
}

\author{
Muhamad Etsya Putra ${ }^{1, *}$, Mirhansyah Ardana², Jaka Fadraersada ${ }^{3}$ \\ ${ }^{1}$ Laboratorium Penelitian dan Pengembangan Kefarmasian "Farmaka Tropis", \\ Fakultas Farmasi, Universitas Mulawarman, Samarinda, Indonesia \\ ${ }^{2}$ Kelompok Bidang Ilmu Farmasetika dan Teknologi Formulasi, Fakultas Farmasi, \\ Universitas Mulawarman, Samarinda, Indonesia \\ ${ }^{3}$ Kelompok Bidang Ilmu Farmasi Klinik dan Komunitas, Fakultas Farmasi, \\ Universitas Mulawarman, Samarinda, Indonesia \\ *Email: etsya.putra@yahoo.com
}

\begin{abstract}
ABSTRAK
Dispensing error adalah kegagalan dalam proses pengobatan berupa pembagian obat yang mengarah atau berpotensi membahayakan pasien dan menyebabkan kerugian pasien. Angka kejadian kesalahan dalam permintaan obat resep cukup tinggi, yaitu antara 0,03 hingga 16,9\%. Dari beberapa kejadian medication error sebesar 3,66\% adalah dispensing error. Penelitian ini dilakukan dengan tujuan untuk mengetahui kejadian medication error berupa dispensing error dalam bentuk keseragaman bobot pada sediaan kapsul racikan di 10 Apotek di Kecamatan Samarinda Ulu. Penelitian ini merupakan penelitian observatif dengan pengambilan data dari resep obat pasien pada beberapa Apotek di Kecamatan Samarinda Ulu periode Juli-September 2017. Hasil penelitian menunjukkan bahwa persentase keseragaman bobot pada sediaan kapsul racikan persentase keseragaman bobot yaitu $30 \%$ memenuhi syarat dan $70 \%$ tidak memenuhi syarat.
\end{abstract}

Kata Kunci: kapsul, keseragaman bobot, medication error, resep

DOI: https://doi.org/10.25026/mpc.v6i1.276

\section{PENDAHULUAN}

Medication error adalah setiap kejadian yang dapat dihindari yang dapat menyebabkan atau berakibat pada pelayanan obat yang tidak tepat atau membahayakan pasien sementara obat berada dalam pengawasan tenaga kesehatan atau pasien (NCCMERP, 2016). Sampai saat ini medication error tetap menjadi salah satu permasalahan kesehatan yang banyak menimbulkan berbagai dampak bagi pasien mulai dari resiko ringan bahkan resiko yang paling parah yaitu menyebabkan suatu kematian (Aronson, 2009).

Konsep medication safety mulai menjadi perhatian dunia sejak November 1999 setelah Institute of Medication (IOM) melaporkan adanya kejadian yang tidak diharapkan (KTD) pada pasien rawat inap di Amerika sebanyak 44.000 bahkan 98.000 orang meninggal karena medical error (kesalahan dalam pelayanan medis) dan 7.000 kasus karena Medication Error. Terjadi atau tidaknya suatu kesalahan dalam pelayanan 
pengobatan terhadap pasien telah menjadi indikator penting dalam keselamatan pasien. Medication error merupakan jenis medical error yang paling sering dan banyak terjadi (Kohn et al., 2000).

Di Indonesia, angka kejadian medication error belum terdata secara akurat dan sistematis, tetapi angka kejadian medication error sangat sering kita jumpai di berbagai institusi pelayanan kesehatan di Indonesia. Angka kejadian akibat kesalahan dalam permintaan obat resep juga bervariasi, yaitu antara 0,03 $16,9 \%$. Dalam salah satu penelitian menyebutkan terdapat $11 \%$ medication error di rumah sakit berkaitan dengan kesalahan saat menyerahkan obat ke pasien dalam bentuk dosis atau obat yang keliru. Meskipun angka kejadian medication error relatif banyak namun jarang yang berakhir hingga terjadi cedera yang fatal di pihak pasien (Dwiprahasto, 2006).

Peresepan obat dalam bentuk racikan (serbuk, serbuk terbagi, kapsul racikan) di Apotek pada kota-kota di Indonesia masih diminati oleh dokter. Terutama sediaan puyer dan kapsul racikan. Hal ini dikarenakan beberapa obat dengan kekuatan utuh untuk dosis dewasa dengan komposisi dan dosis tertentu tidak tersedia dalam bentuk sediaan jadi. Obat ini dapat dipersiapkan dalam bentuk kapsul racikan untuk mempermudah penggunaan obat pada pasien. Sediaan kapsul memiliki keuntungan dapat menutupi rasa dan bau obat yang kurang enak. Sediaan kapsul juga dapat memudahkan dalam penggunaannya karena dapat diberikan campuran kombinasi bahan obat dan dosis yang lebih tepat sesuai dengan kebutuhan individu (Syamsuni, 2007).

Dalam penulisan resep biasanya pembagian serbuk terbagi dalam pembuatan sediaan puyer maupun kapsul raikan dibagi secara merata di kertas perkamen dengan cara visual. Cara visual merupakan metode pembagian dengan cara membagi obat yang telah digerus ke kertas perkamen secara visual dengan jumlah yang telah ditetapkan dan cara ini yang paling banyak dilakukan di apotek karena cepat dan praktis. Namun cara ini memiliki banyak kelemahan, antara lain kurang dapat menjamin keseragaman dalam tiap puyer dan kapsul racikan.

Karena itu jumlah kapsul yang diinginkan akan mempengaruhi pembagian serbuk dalam kapsul racikan sehingga diperoleh bobot sediaan yang seragam. Permasalahan lain yang akan timbul terkait dengan peracikan sediaan kapsul racikan adalah homogenitas, keseragaman bobot, kehalusan partikel obat dan pemilihan metode yang tepat dalam proses peracikan kapsul racikan dengan benar (Syamsuni, 2007).

Berdasarkan latar belakang diatas, didapat rumusan masalah yaitu : (a) Berapakah data dispensing error pada sediaan kapsul racikan di 10 apotek sekitar wilayah Kecamatan Samarinda Ulu?, (b) Berapakah persentase dispensing error dalam bentuk keseragaman bobot pada sediaan kapsul racikan dari 10 apotek di wilayah Kecamatan Samarinda Ulu?

\section{METODE PENELITIAN}

Penelitian yang dilakukan tergolong penelitian observatif, yaitu penelitian yang dilakukan dengan tujuan utama untuk penjabaran data dan membuat gambaran atau deskriptif tentang suatu keadaaan secara objektif. Pengambilan sampel dilakukan pada 10 Apotek wilayah kecamatan Samarinda Ulu. Pengambilan sampel uji diambil tiap apotek sebanyak 1 sampel sediaan kapsul racikan dari tiap 10 apotek yang telah dipilih. Pengujian keseragaman bobot sediaan sesuai Uji Keseragaman Bobot menurut Farmakope Indonesia edisi III (FI III). Persentase penyimpangan ditentukan terhadap bobot isi rata-rata. Sampel yang digunakan dalam penelitian ini adalah sediaan kapsul racikan yang diresepkan oleh dokter praktek dan dilakukan pengambilan 
sampel dan perhitungan data pada bulan Juli-September 2017 di 10 apotek sekitar wilayah kecamatan Samarinda Ulu.

\section{HASIL DAN PEMBAHASAN}

Penelitian ini dilakukan dengan mengambil sampel sebanyak 10 sampel kapsul racikan yang diambil dari 10 apotek wilayah Kecamatan Samarinda Ulu periode Juli-September 2017. Peresepan sediaan kapsul racikan diperoleh dari dokter praktek di klinik maupun apotek yang praktek di wilayah
Kecamatan Samarinda Ulu. Setelah itu, menebus resep ke apotek-apotek yang terdapat disekitar wilayah Kecamatan Samarinda Ulu. Selanjutnya, diambil sediaan kapsul racikan yang telah diracik. Setelah itu sediaan dibawa ke laboratorium penelitian untuk dilakukan penimbangan bobot dan evaluasi dispensing error dalam bentuk keseragaman bobot. Hasil persentase jumlah yang menyimpang terhadap bobot rata-rata dapat dilihat pada tabel 1 .

Tabel 1. Tabel Persentase Sediaan Kapsul Racikan Apotek A-Apotek J

\begin{tabular}{cccc}
\hline \multirow{2}{*}{ No. } & Lokasi & m.s & Jumlah \\
\cline { 3 - 4 } & & 5 & 5 \\
1. & Apotek A & 6 & 4 \\
2. & Apotek B & 4 & 6 \\
3. & Apotek C & 7 & 3 \\
4. & Apotek D & 10 & - \\
5. & Apotek E & 5 & 5 \\
6. & Apotek F & 10 & - \\
7. & Apotek G & 5 & 5 \\
8. & Apotek H & 7 & 3 \\
9. & Apotek I & 10 & - \\
10. & Apotek J & memenuhi syarat ( jika penyimpangan $\leq 15 \%$ dari bobot rata \\
\hline Keterangan : m.s m & rata berdasarkan FI III) &
\end{tabular}

Berdasarkan data yang diperoleh pada tabel diatas, dispensing error pada keseragaman bobot terjadi atau tidak memenuhi syarat berdasarkan literatur FI Edisi III menerangkan bahwa rentang sedian kapsul yang diperbolehkan pada bobot rata-rata isi kapsul lebih dari $120 \mathrm{mg}$ yaitu diperbolehkan pada perbedaan dalam persen bobot isi tiap kapsul terhadap bobot rata rata isi kapsul tidak lebih dari 7,5\%. Sehingga dapat disimpulkan bahwa dispensing error dalam bentuk keseragaman bobot terjadi pada Apotek A dengan kode kapsul 1,2,7,8 dan 9 sudah jelas tidak masuk dalam rentang kapsul yang diperbolehkan karena lebih dari 7,5\%. Apotek B dengan kode kapsul 2,5,7 dan 8 sudah jelas tidak masuk dalam rentang kapsul yang diperbolehkan karena lebih dari 7,5\%. Apotek C dengan kode kapsul 2,4,5,6,8 dan 9 sudah jelas tidak masuk dalam rentang kapsul yang diperbolehkan karena lebih dari 7,5\%. Apotek D dengan kode kapsul 3,6 dan 8 sudah jelas tidak masuk dalam rentang kapsul yang diperbolehkan karena lebih dari 7,5\%. Apotek F dengan kode kapsul 1,2,7 dan 8 sudah jelas tidak masuk dalam rentang kapsul yang diperbolehkan karena lebih dari 7,5\%. 
Apotek H dengan kode kapsul 2,4,6,8 dan 9 sudah jelas tidak masuk dalam rentang kapsul yang diperbolehkan karena lebih dari 7,5\%. Apotek I dengan kode kapsul 3,6 dan 8 sudah jelas tidak masuk dalam rentang kapsul yang diperbolehkan karena lebih dari $7,5 \%$. Pada persentase yang terdapat pada Apotek A,B,C,D,F,H, dan I terlihat bahwa terjadi penyimpangan bobot dengan bobot rata-ratanya ditandai dengan lebih dari satu kapsul yang penyimpangannya lebih dari $7,5 \%$. Hal ini dapat disimpulkan bahwa keseragaman bobot dalam sediaan kapsul kurang baik dan tidak memenuhi persyaratan yang ditetapkan Depkes RI (1979) dimana tidak lebih dari satu kapsul yang bobotnya menyimpang lebih dari 7,5\% bobot rataratanya. Sedangkan tidak terjadi dispensing error atau memenuhi syarat yaitu pada Apotek E,G dan Apotek J dimana semua kode kapsul 1-10 masuk dalam rentang karena penyimpangan bobot dengan bobot rata-ratanya tidak lebih dari $7,5 \%$ yang terdapat pada Farmakope Edisi ke-III. Terjadinya error pada Apotek A,B,C,D,F,H, dan I, hal ini menunjukkan adanya kesalahan dalam proses peracikan kapsul. Kaidah pembagian kapsul adalah dengan penglihatan, sehingga hasilnya sangat dipengaruhi oleh kondisi mata reseptir. Banker dan chalmer (1982) menyatakan bahwa sungguh sulit untuk memperoleh dosis (kadar) yang akurat pada kapsul karena sangat ditentukan oleh faktor manusia. Hal ini tentunya sangat memprihatinkan karena batasan kadar dalam suatu sediaan merupakan faktor yang essensial untuk suksesnya suatu terapi. Sehingga jika bobot sediaan kapsul tidak seragam maka dapat menganggu atau tidak suksesnya suatu terapi karena kemungkinan jika bobot berlebih dapat menimbulkan efek samping yang berlebihan dan jika bobot kurang tidak tercapainya efek terapi yang diinginkan. Sehingga sebaiknya upaya yang dilakukan untuk meminimalisir terjadinya error akibat faktor manusia yaitu apoteker atau reseptir lebih hati-hati dan waspada dalam peracikan dan pemilihan nomor cangkang kapsul yang digunakan serta perlu dilakukan penimbangan bobot terlebih dahulu untuk mengurangi kesalahan dapat dilakukan dengan cara ditimbang serbuk sebelum dimasukkan kedalam cangkang kapsul kemudian dibagi dalam jumlah yang diminta dalam resep.

Penelitian ini merupakan penelitian observatif semi kuantitatif, untuk mengetahui angka kejadian dispensing error di apotek sekitar kecamatan Samarinda Ulu. Berdasarkan penelitian yang telah dilakukan diperoleh sampel sebanyak 10 sampel puyer dan kapsul racikan yang diambil dari 10 apotek wilayah kecamatan Samarinda Ulu periode Juli-September 2017

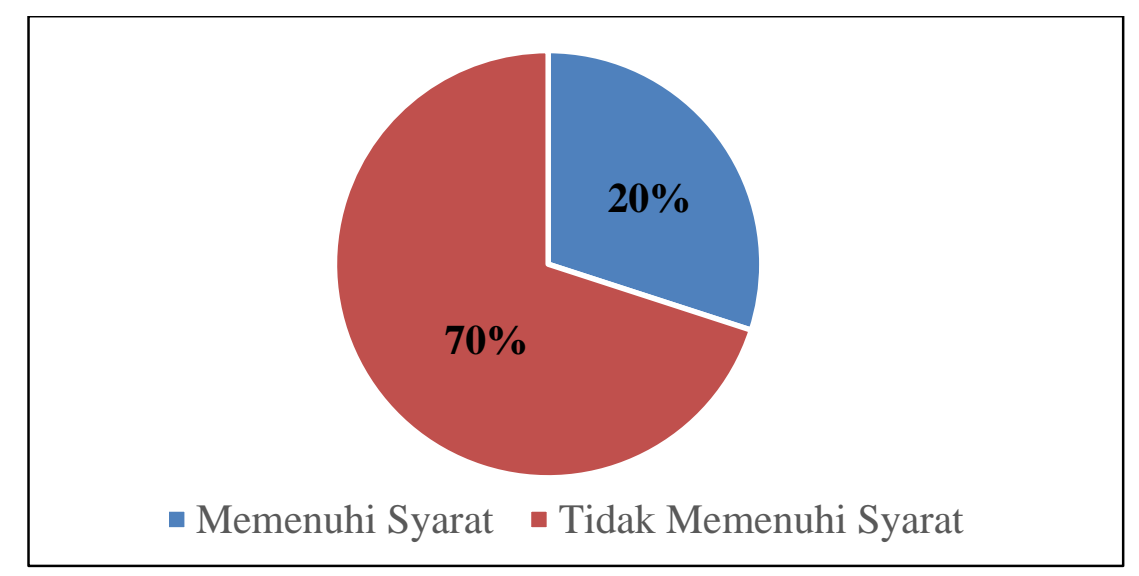

Gambar 1. Diagram Persentase Keseragaman Bobot Kapsul Racikan 
Berdasarkan diagram diatas dapat disimpulkan bahwa masih terjadi medication error berupa dispensing error pada sediaan kapsul racikan di Apotek wilayah Kecamatan Samarinda Ulu, ditunjukkan pada sediaan kapsul racikan yaitu dari 10 apotek yang membuat kapsul hanya 3 yang memenuhi persyaratan keseragaman bobot atau hanya 30\% dari jumlah kapsul yang di teliti. Hal ini tentunya sangat memprihatinkan. Karena batasan kadar dalam suatu sediaan merupakan faktor yang essensial untuk suksesnya suatu terapi. Sehingga jika bobot sediaan kapsul racikan tidak seragaman, maka dapat menganggu atau tidak suksesnya suatu terapi. Apoteker pengelola apotek (APA) yang secara hukum betanggung jawab dalam mencampur dan menyerahkan obat atau bahan obat kepada pasien untuk melakukan pekerjaan pekerjaan kefarmasian. Keberadaan APA pada jam buka apotek sangat relevan dengan pengelolaan apotek secara profesional, sehingga kesalahan yang disebabkan oleh faktor manusia dapat diminimalkan. Hal ini sesuai dengan penelitian Handayani tahun 2008, keseragaman bobot yang terjadi di Kota Klaten dimana hanya $40 \%$ yang memenuhi syarat sehingga masih terjadi medication error berupa dispensing error dan hal ini berbanding terbalik dengan penelitian Helni tahun 2014 yang dilakukan di Kota Jambi dimana $81,25 \%$ masih memenuhi keseragaman bobot sehingga tidak terjadi medication error berupa dispensing error. Terjadinya error menunjukkan adanya kesalahan dalam proses peracikan sediaan kapsul racikan. Kaidah pembagian kapsul racikan adalah dengan penglihatan, sehingga hasilnya sangat dipengaruhi oleh kondisi mata reseptir, untuk mengurangi kesalahan dapat dilakukan dengan membagi kapsul racikan dengan cara ditimbang kemudian dibagi dalam jumlah yang dimintain dalam resep. Dari data yang didapat keseragaman bobot pada sediaan kapsul racikan lebih baik, hal ini karena kemungkinan pembagian serbuk dalam cangkang kapsul di beberapa Apotek sudah sesuai dalam pemilihan nomor cangkang kapsul dan serbuk yang dimasukkan ke dalam cangkang tidak ada yang terbuang.

Saran untuk kedepannya yaitu sebaiknya dalam pembagian serbuk sebelum di masukkan kedalam cangkang kapsul sebaiknya dilakukan penimbangan terlebih dahulu menggunakan timbangan analitik agar lebih seragam bobot yang dihasilkan dari tiap tiap kapsul.

\section{KESIMPULAN}

Berdasarkan hasil penelitian dapat disimpulkan bahwa masih terjadi medication error berupa dispensing error dalam bentuk keseragaman bobot yaitu sebesar 70\% yang masih tidak memenuhi syarat dari 10 Apotek wilayah Kecamatan Samarinda Ulu.

\section{DAFTAR PUSAKA}

[1]. NCCMERP. 2016. Medication errors.

[2]. Aronson JK. 2009. Medication errors : definitions and classification. $\mathrm{Br} \mathrm{J}$ Clin Pharmacol.6(67):599-604.

[3]. Institute of Medicine (IOM). 2001. Crossing the quality chasm. Journal National Academy Press, Washington DC.;21(3): 81-90.

[4]. Kohn L, Corrigan J, Donaldson M. 2000. To err is human : building a safer health system. Report of the committee on quality of health care in America, institute of medicine, ashington. National Academy Press

[5]. Dwiprahasto I. 2006, Intervensi pelatihan untuk meminimalkan risiko medication error di pusat pelayanan kesehatan primer. Jurnal Berkala Ilmu Kedokteran 2006, XXXVIII(1).

[6]. Syamsuni, Apt. 2007. Ilmu resep. Jakarta: EGC 